\title{
Technological and Nutritional Aspects of Incorporating Jamun (Syzygium cumini (L.) Skeels) Fruit Extract into Yoghurt
}

\author{
Emam $\mathrm{AO}^{1} \&$ Heba AS El-Nashar ${ }^{2,3}$ \\ ${ }^{1}$ Faculty of Agriculture, Department of Food Science, Ain Shams University, Cairo, Egypt \\ ${ }^{2}$ Faculty of Pharmacy, Department of Pharmacognosy, Ain Shams University, Cairo, Egypt \\ ${ }^{3}$ Center of Drug Discovery Research and Development, Ain Shams University, Cairo, Egypt \\ Correspondence: Emam AO, Faculty of Agriculture, Department of Food Science, Ain Shams University, Cairo, \\ Egypt. E-mail: ahmed.osama@agr.asu.edu.eg
}

Received: December 2, 2021

Accepted: January 15, 2022 Online Published: January 21, 2022

doi:10.5539/jfr.v11n1p28

URL: https://doi.org/10.5539/jfr.v11n1p28

\begin{abstract}
The study aimed to evaluate the technological suitability of incorporating the jamun extracts into Yoghurt. The light focused on the effect of the extraction method and rate of addition on the flavonols profiles, antioxidant activity and sensorial characteristics of the final Yoghurt product. Jamun fruit was subjected to either mechanical cold extraction or steam extraction and introduced to milk at rates of 5 and $10 \%$. The results indicated that the extraction technique had no effect on the values of protein, fat, ash and titratable acidity. The steam extraction led to increase the total solids, $\mathrm{pH}$, total hydrolysable tannins, antioxidant activity, color, flavor and overall sensorial acceptability of Yoghurt. While the cold mechanical extraction led to increase the total flavonols, thickness and smell scoring. Increasing the percentage of jamun extract addition led to reduce the total solids, protein, fat, appearance and thickness in a concentration depending way, as well as to increase all the detected flavonols, tannins and antioxitant power indicators. The 5\% juice containing Yoghurt was distinguished with the highest scores of color, flavor, taste, smell and overall acceptability. Jamun fruit may be a promising source for fortifying Yoghurt with flavonols and enhancing its antioxidant power.
\end{abstract}

Keywords: blackberry, java plum, scavenging, tannins

\section{Introduction}

The consumer demand for functional food and dairy products is in a continuous increase due to the health benefits they reflect, leading to the research and development of different functional food products (Abdel-Hamid et al., 2020). Moreover, the concern with the immunity boosting foods has been increased many folds with the outbreak of covid-19. Jamun fruit or Syzygium cumini is one of the family Myrtaceae well-known plants. It is commonly known as Indian Blackberry, Jambul, Black Plum and Java Plum. It is a health stimulating fruit and contains many phytochemicals incorporated in different parts of the tree including leaf, seed, and pulp. Due to its richness of these phytochemicals, it is used to treat several diseases in tropical Aisha such as allergies, viral infection, gastric ulcer, cancer and diabetes mellitus (Chaudhary \& Mukhopadhyay, 2012; Joshi, Paudel \& Upreti, 2019). In the traditional medicine, jamun was known to be anti-stomach pain, anti-scorbutic, carminative, and diuretic. Moreover, black plum vinegar is good to reduce enlargement of spleen and diarrhea. Jamun fruit with its polyphenol compounds has attracted the attention of the food manufacturers, as a potential material for the fortification and development of several functional food products and meals. In Europe, jamun was known as a delicacy and sold in a dried form (Singh et al., 2016). It was used also for the preparation of bread, pulp, jelly and wine (Branco et al., 2016; Kapoor, Ranote \& Sharma, 2015). On the other hand, Yoghurt is commonly consumed as a functional food due to its nutritional value besides its richness in the bioactive peptides with antioxidant power that are produced by the action of the lactic acid bacteria fermentation (Muniandy, Shori \& Baba, 2016). Yoghurt is a very good source of protein, fat, phosphorus, thiamin, riboflavin, vitamin B12, niacin, calcium, magnesium, and zinc. Consumption of Yoghurt has considered to be beneficial to digestion and overall health (Morelli \& Yogurt, 2014). It causes a decrease in the stomach pH, which in turn lowers the potential risk of pathogen transition and ameliorates the improper effects of the reduced gastric juice secretion and hence any acidic supplementation to Yoghurt is beneficial to enhance these effects. Yogurt is always flavored by application of natural substances or artificial flavoring preparations (Coïsson et al., 2005). Fruit extracts: specially 
strawberries, blueberries and raspberries are widely used to provide Yoghurt with natural colors, flavors and bioactive compounds, those berries are commonly considered as functional components in the food and dairy manufacture (Wallace \& Giusti, 2008). The impact of different functional fruit extracts on the sensorial, physicochemical, antioxidant and nutritional properties of fruit yoghurt have been evaluated (Kim et al., 2009; Oh \&Kang, 2015; Nguyen \& Hwang, 2016), but jamun extracts have not been evaluated in that concern. For that in view, the present study was conducted to evaluate the technological suitability of incorporating the jamun cold and steam extracts into fruit Yoghurt with the light on the effect of the extraction method and rate of addition on the flavanols' profiles, antioxidant activity and sensorial characteristics of the final Yoghurt product.

\section{Materials and Methods}

\subsection{Materials}

Skimmed milk powder was obtained from Fonterra brands, Ltd - New Zealand (3.8\% moisture, 34\% protein, 1.5\% fat and $8.3 \%$ ash). Cow's fresh cream (56.5\% fat, $0.371 \%$ ash and $1.71 \%$ protein) was obtained from Shahencoland company for dairy products, Foah, Egypt. Concentrated lyophilized mixed yoghurt starter culture (YC-183) contains Str. thermophilus and Lb. delbrueckii ssp. bulgaricus, 1:1, were obtained from Chr. Hansen Lab., Denmark. Sucrose was obtained from Savola, Egypt. Frozen Brazilian Jamun (Syzygium cumini L. Skeels) fruit was provided with confirmed identity by Diamond Company for food industries and import, El-Obour, Egypt.

\subsection{Experimental Procedure}

\subsubsection{Preparation of the Jamun Juices}

The frozen Jamun fruits were allowed to thaw at the room temperature for about $2 \mathrm{~h}$ and washed using running water. The flesh with skins of fruits was separated manually from the seed. The prepared flesh fruit parts were divided to two portions and then the fruit juice was either mechanically extracted at $5{ }^{\circ} \mathrm{C}$ by blending in a processing blender at $1500 \mathrm{rpm}$ or extracted by steam in a stainless steel proper steamer pan at $85 \pm 5^{\circ} \mathrm{C}$ for $2 \mathrm{~h}$. the extracted two forms of juice were filtered with clean cloth and packed in sterile plastic bags and stored at $-18^{\circ} \mathrm{C}$ until use.

\subsubsection{Manufacturing of Jamun Fruit Yoghurt}

The method of Kulshrestha \& Jha, 2006 was applied with some modifications as the powdered Skim milk was reconstituted in water at $40^{\circ} \mathrm{C}$ and standardized with the fresh cream to obtain full cream milk containing $14 \%$ total solids and 3.5\% fat. The standardized yoghurt milk was heated to $65^{\circ} \mathrm{C}$, and then homogenized at 2500 and $500 \mathrm{psi}$ for the first and second stage respectively. Sucrose was added at a rate of $6 \%$ and mixed well. The sweetened milk was heated at $90^{\circ} \mathrm{C}$ for $8 \mathrm{~min}$., cooled to $42^{\circ} \mathrm{C}$, inoculated with $2 \%$ of freshly activated YC starter culture and divided to 5 equal portions; the cold extracted Jamun juice was added with stirring to the $1^{\text {st }}$ and $2^{\text {nd }}$ portions at rates of 5 and $10 \%$ respectively. The steam extracted Jamun juice was added to the $3^{\text {rd }}$ and $4^{\text {th }}$ portions at the same rates. The $5^{\text {th }}$ portion was for the control yoghurt without fruit juice. All the experimental samples were packaged in $150 \mathrm{ml}$ poly stearin cups with closers. The filled cups were incubated at $40^{\circ} \mathrm{C}$ for $4 \mathrm{~h}$, and then kept at $5{ }^{\circ} \mathrm{C}$ until use.

2.2.3 Preparation of Fruit Yoghurt Samples for the Determination of Flavonols and Hydrolysable Tannins Profiles

A portion of $100 \mathrm{~g}$ of each Yoghurt sample was subjected to three times of extraction to recover the polyphenols. The samples were dissolved in $50 \mathrm{ml}$ of a solvent mixture of methanol, water, and formic acid (50:48.5:1.5, v/v resp.), subjected to an ultrasonic agitation for $10 \mathrm{~min}$, and were then centrifuged at $2.500 \mathrm{~g}$ and $5{ }^{\circ} \mathrm{C} / 10 \mathrm{~min}$. The obtained supernatants were then combined into a single extract, roto-evaporated at $35{ }^{\circ} \mathrm{C}$ and lyophilized. aliquots of $3 \mathrm{ml}$ of Yoghurt samples extracts were subjected to solid-phase extraction on Bond Elut Plexa PCX cartridges (Agilent; $6 \mathrm{~cm} 3,500 \mathrm{mg}$ of adsorbent) to remove interfering anthocyanins (Castillo-Muñoz et al., 2009). These anthocyanin-free extracts were filtered through $0.20-\mu \mathrm{m}$ membrane and injected directly on the chromatographic column $(20 \mu \mathrm{L})$. The total concentrations of gallotannins and ellagitannins were estimated after acidic hydrolysis of anthocyanin-free extracts as described by Peng, Scalbert \& Monties, 1991. The hydrolyzed extracts were then homogenized, filtered, and injected directly on the chromatographic column $(20 \mu \mathrm{L})$.

\subsection{Analytical Methods}

\subsubsection{Determination of the Physicochemical Properties of the Fruit Yoghurt}

Total nitrogen, dry matter, fat, ash, and titratable acidity contents were determined according to AOAC, 2007. The $\mathrm{pH}$ values were measured using a microprocessor $\mathrm{pH}$ meter (model 8417, Hanna Instruments, Singapore) at 
$20^{\circ} \mathrm{C}$.

\subsubsection{Determination of Flavonols, and Hydrolysable Tannins in the Fruit Yoghurt using HPLC-DAD-ESIMS ${ }^{\mathrm{n}}$}

The method of Tavares et al., 2016 was followed to analyze the phenolic extracts of fruit Yoghurt samples. HPLC separation, identification, and quantitation were performed using an Agilent 1100 Series HPLC system equipped with DAD (G1315B) and an LC/MSD Trap VL (G2445C VL) ESI-MSn detectors, coupled to an Agilent ChemStation (version B.01.03) data-processing station. The mass spectra data were processed using the Agilent LC/MS Trap software (version 5.3). A Zorbax Eclipse XDB reversed-phase-C18 column $(2.1 \times 150 \mathrm{~mm}$, $3.5 \mu \mathrm{m}$ particle) was used and maintained at $40{ }^{\circ} \mathrm{C}$ with a $0.19 \mathrm{~mL} / \mathrm{min}$ flow rate. The identification was depended on spectroscopic data of UV-Vis and MS/MS for standards or data from previous research reports of Castillo-Muñoz et al., 2009 and Tavares et al., 2016. Quantitative determination of polyphenols was carried out by extraction of the DAD chromatograms at $360 \mathrm{~nm}$ for flavonols and by the external standard method. All calibration standard solutions were prepared by dilution of an appropriate aliquot of the stock solution of M3glc (from 5 to $100 \mathrm{mg} / \mathrm{L}$ ) for flavonols. All calibration curves of components showed good linearity. The total concentrations of the flavonols were expressed as $\mathrm{mg}$ of M3glc equivalents, per $1 \mathrm{~L}$ or $\mathrm{kg}$ of sample.

The method of Peng, Scalbert \& Monties, 1991 was applied for the determination of hydrolysable tannins using HPLC. The identification of hydrolysable tannins was based on spectroscopic data (UV-Vis and MS/MS) for standards. For quantitation, DAD chromatograms were extracted at $280 \mathrm{~nm}$ and calibration curves of gallic (from 5 to $100 \mathrm{mg} / \mathrm{L}$ ) and ellagic acids (from 5 to $40 \mathrm{mg} / \mathrm{L}$ ) were prepared, as described for flavonols. The total concentrations of gallotannins and ellagitannins were expressed in $\mathrm{mg}$ of gallic acid equivalents and in $\mathrm{mg}$ of ellagic acid equivalents, respectively, per $1 \mathrm{~L}$ of sample.

\subsubsection{Determination of the Antioxidation Power Indicators of the Jamun Fruit Yoghurt}

The DPPH radical scavenging activities of plain and fruit yogurt samples were determined according to the method of Cheung, Cheung \& Ooi, 2003 with some modifications as follows: $192 \mu \mathrm{L}$ of $50 \mu \mathrm{M}$ DPPH was added with mixing to $48 \mu \mathrm{L}$ of diluted sample. The mixture was covered and kept in the dark at room temperature for $30 \mathrm{~min}$. The control consisted of $48 \mu \mathrm{L}$ distilled water in $192 \mu \mathrm{L}$ of $50 \mu \mathrm{M}$ DPPH for the ascorbic acid standard or $48 \mu \mathrm{L}$ of $94 \%$ ethanol in $192 \mu \mathrm{L}$ of $50 \mu \mathrm{M}$ DPPH for the test samples. Decolorization of DPPH was measured at $517 \mathrm{~nm}$ with a micro-plate reader. The DPPH radical scavenging activity was calculated according to the following equation: Inhibition $(\%)=\mathrm{I}_{\text {control }}-\mathrm{I}_{\text {sample }} / \mathrm{I}_{\text {control }} \mathrm{x} 100$, where $\mathrm{I}_{\text {control }}$ is the absorbance of the control reaction which contains all reagents except the test compound, and $\mathrm{I}_{\text {sample }}$ is the absorbance of the test compound. The ABTS radical scavenging activities of plain and fruit yogurt samples were determined using the method of Re et al., 1999 with slight modifications. ABTS was dissolved in distilled water to a concentration of $7 \mathrm{mM}$. ABTS radical cations were produced by reacting the ABTS stock solution with 2.45 $\mathrm{mM} \mathrm{K} \mathrm{S}_{2} \mathrm{O}_{8}$ (in a 2:1 ratio) in the dark, covered for $24 \mathrm{~h}$ before use. The ABTS reagent was diluted with $94 \%$ ethanol to the appropriate absorbance $(0.17 \pm 0.03)$, which was measured at $734 \mathrm{~nm}$. The ABTS reagent $(950 \mu \mathrm{L})$ was mixed with $50 \mu \mathrm{L}$ of the indicated concentrations of test samples. The mixture was covered and kept in the dark at room temperature for $10 \mathrm{~min}$. The absorbance at $734 \mathrm{~nm}$ was measured with a micro-plate reader. Each sample was measured in triplicate, and percent inhibition was calculated using the same equation of calculating the DPPH. To assay the reducing power, the ferric reducing power of yogurt samples was determined using the method of Oyaizu, 1986 with slight modifications. Various concentrations of samples $(0.25 \mathrm{~mL})$ were mixed with $0.25 \mathrm{~mL}$ of $0.2 \mathrm{M}$ phosphate buffer $(\mathrm{pH} 6.6)$ and $0.25 \mathrm{~mL}$ of $1 \%(\mathrm{w} / \mathrm{v}) \mathrm{K}_{3}\left[\mathrm{Fe}(\mathrm{CN})_{6}\right]$. The mixture was incubated in a $50^{\circ} \mathrm{C}$ water bath for $20 \mathrm{~min}$, and their action was stopped by adding $0.25 \mathrm{~mL}$ of $10 \%(\mathrm{w} / \mathrm{v})$ trichloroacetic acid solution. The solution was then centrifuged at $3000 \mathrm{rpm}$ for $10 \mathrm{~min}$. The supernatant $(0.5 \mathrm{~mL})$ was mixed with $0.5 \mathrm{~mL}$ of distilled water and $0.1 \mathrm{~mL}$ of $0.1 \%$ (w/v) $\mathrm{FeCl}_{3}$ for $10 \mathrm{~min}$. The reducing power was determined by measuring the absorbance at $700 \mathrm{~nm}$ with a microplate reader. A standard curve of ascorbic acid was generated with concentrations ranging from 0 to $200 \mu \mathrm{g} / \mathrm{mL}$.

\subsubsection{Sensory Evaluation of the Jamun Fruit Yoghurt}

The samples were evaluated for sensorial characteristics after 3 days from manufacturing by 5 panellists who are working in the dairy manufacture and familiar with the Yoghurt acceptability criteria; using nine-point hedonic scales as described by Obi, Henshaw \& Atanda, 2010.

\subsubsection{Statistical Analysis}

The obtained data were statistically analyzed through the ANOVA procedure and Duncan's multiple range tests according to statistical analyses system user's guide; SAS/STAT ${ }^{\circledR}$ 9.1. SAS, Inst Inc Ed Cary NC USA (SAS, 2004). Design was completely random with replications. 


\section{Results and Discussion}

\subsection{Physicochemical Properties of the Jamun Fruit Yoghurt}

Data shown in Table (1) revealed that, all studied factors had significant effect on the total solids of the jamun Yoghurt. The steam extracted juice addition to milk led to significantly increase the total solids of Yoghurt as compared to the addition of the juice extracted by the cold blending method. That could be due to the strong effect of stem in breaking the fruit cells leading to increasing the extraction efficiency (Chen \& Chen, 2011). This phenomenon was supported by the findings of Astuti et al., 2018 who concluded that the total soluble solids increase by increasing the heat treatment degree. The total solids contents were decreased by increasing the percentage of jamun fruit juice addition, possible due to the lower total solids' contents of the extracted juices than that of the standardized yoghurt milk. The protein and fat contents of the yoghurt samples containing the cold extracted jamun juice were statistically like those having the steam extracted juice. Likewise, the increase in the rate of jamun juice addition to the milk led to decrease the protein and fat of the resultant Yoghurt significantly. That could be ascribed essentially to the extremely low protein and fat contents in the jamun fruit flesh (Ghosh et al., 2016). Regarding the ash contents, the statistical analysis indicated that the two studied factors had no significant impact on the ash contents of the experimental samples. The cold extracted jamun fruit Yoghurt samples obtained higher titratable acidity than the steam extracted fruit yoghurt ones, possibly due to the damage occurred to the organic acids during steam heating. The addition of jamun fruit juice to milk led to increase the titratable acidity of the final yoghurt regardless the method of juice extraction and the rate of addition as Yoghurt with 5\% juice had statistically similar titratable acidity to that made with $10 \%$ juice. That could be attributed to that the applied method for acidity determination was customized to measure the lactic acid. Likely, the cold extracted jamun fruit Yoghurt samples were distinguished with lower $\mathrm{pH}$ values than those of the other method of juice extraction. The fruit yoghurt having $10 \%$ juice obtained statistically similar $\mathrm{pH}$ to that having 5\% juice, and lower than the control Yoghurt. That could be ascribed essentially to the strong buffering capacity of milk proteins which in turn kept the $\mathrm{pH}$ of Yoghurt unchanged when the rate of juice addition was increased from 5 to $10 \%$. The round figures of these results are in accordance with the finding of Rahman et al., 2020.

Table 1. Ls means values for method of Jamun fruit juice extraction, percent of juice addition and method of Jamun fruit juice extraction $x$ percent of juice addition on the physicochemical properties of the Jamun fruit yoghurt

\begin{tabular}{|c|c|c|c|c|c|c|}
\hline Source of variation & $\begin{array}{l}\text { Total } \\
\text { Solids (\%) }\end{array}$ & Protein (\%) & Fat $(\%)$ & $\operatorname{Ash}(\%)$ & $\begin{array}{l}\text { Titratable } \\
\text { acidity (\%) }\end{array}$ & $p H$ \\
\hline \multicolumn{7}{|c|}{ Method of Jamun fruit juice extraction (M) } \\
\hline Cold blending at $1500 \mathrm{rpm}$ & $18.55^{\mathrm{b}}$ & $3.50^{\mathrm{a}}$ & $3.27^{\mathrm{a}}$ & $0.566^{\mathrm{a}}$ & $0.86^{\mathrm{a}}$ & $4.20^{\mathrm{b}}$ \\
\hline Stem at $85 \pm 5^{\circ} \mathrm{C}$ for $2 \mathrm{~h}$. & $18.77^{\mathrm{a}}$ & $3.50^{\mathrm{a}}$ & $3.26^{\mathrm{a}}$ & $0.573^{\mathrm{a}}$ & $0.83^{\mathrm{a}}$ & $4.40^{\mathrm{a}}$ \\
\hline$P$ value & 0.0019 & 1.0000 & 0.9094 & 0.9004 & 0.6026 & 0.0045 \\
\hline \multicolumn{7}{|c|}{ Percentage of Jamun fruit extract addition $(\mathrm{P})$} \\
\hline $0 \%$ (control) & $19.00^{\mathrm{a}}$ & $3.69^{\mathrm{a}}$ & $3.43^{\mathrm{a}}$ & $0.584^{\mathrm{a}}$ & $0.67^{\mathrm{b}}$ & $4.47^{\mathrm{a}}$ \\
\hline $5 \%$ & $18.64^{\mathrm{b}}$ & $3.50^{\mathrm{b}}$ & $3.26^{\mathrm{b}}$ & $0.570^{\mathrm{a}}$ & $0.93^{\mathrm{a}}$ & $4.26^{\mathrm{b}}$ \\
\hline $10 \%$ & $18.34^{\mathrm{c}}$ & $3.33^{\mathrm{c}}$ & $3.10^{\mathrm{c}}$ & $0.556^{\mathrm{a}}$ & $0.94^{\mathrm{a}}$ & $4.19^{\mathrm{b}}$ \\
\hline$P$ value & $<.0001$ & 0.0009 & 0.0021 & 0.9241 & 0.0031 & 0.0048 \\
\hline \multicolumn{7}{|l|}{ M X P } \\
\hline Control & 19.00 & 3.69 & 3.43 & 0.584 & 0.67 & 4.47 \\
\hline Cold blending x $5 \%$ & 18.53 & 3.50 & 3.27 & 0.566 & 0.95 & 4.15 \\
\hline Cold blending x $10 \%$ & 18.12 & 3.33 & 3.11 & 0.549 & 0.97 & 4.00 \\
\hline Steam extraction $x 5 \%$ & 18.76 & 3.50 & 3.26 & 0.574 & 0.91 & 4.37 \\
\hline Steam extraction $\mathrm{x} 10 \%$ & 18.57 & 3.33 & 3.10 & 0.563 & 0.92 & 4.38 \\
\hline Pvalue & 0.0245 & 1.0000 & 0.9966 & 0.9950 & 0.9299 & 0.0564 \\
\hline
\end{tabular}

Values with different letters (a-c) within the same column are significantly different at $\mathrm{P}<0.05$.

\subsection{Flavonols Spectral Characterization of the Jamun Fruit Yoghurt}

Data shown in Table (2) elucidated that the identified flavonols in the experimental jamun fruit Yoghurt samples were the Bring tri-substituted aglycones: laricitrin (L), myricetin (M) as well as syringetin (S) with their derivatives; 3-galactoside, 3-glucoside, 3-rhamnoside, 3-pentoside and 3-glucuronide. Moreover, free syringetin and myricetin were detected in all the Yoghurt samples, while free laricitrin was detected only in the steam 
extracted jamun Yoghurt. The flavonols from quercetin, isorhamnetin or kaempferol were not detected in all samples. The cold extracted jamun fruit Yoghurt samples were distinguished with higher amounts of the flavonols: M3glcU, M3gal, M3glc, M3rhm, M3pent, L3gal, S3gal and free S than the steam extracted jamun fruit Yoghurt which gained the highest levels of L3glc, S3glc, Free M and Free L. The latter free laricitrin flavonol was considerably detected only when the steam extraction was applied to prepare the jamun fruitextract, possible due to role of heating in the degradation of the cell walls and the hydrolysis of flavonol glycosides leading to releasing aglycones. Similar observations were reported by Teleszko, Nowicka \& Wojdyło, 2016 who studied the factors affecting the polyphenols content in strawberry cloudy juices. Nevertheless, the application of cold blending at $1500 \mathrm{rpm}$ to jamun fruit led to attain the highest level in $\mathrm{mg} / \mathrm{L}$ of Yoghurt total flavonols when compared to the steam extraction method. The statistical analysis confirmed that the flavonols contents of the fruit Yoghurt were increased by increasing the percentage of added juice, regardless the method of juice extraction. It's noteworthy to mention that the average total favonols content of the cold extracted jamun fruit yoghurt was about $5.5 \%$ of the proportion of total falvonols in the jamun fruit itself.

Table 2. Ls means values for method of Jamun fruit juice extraction, percent of juice addition and method of Jamun fruit juice extraction x percent of juice addition on the flavonols content by HPLC-DAD-ESI-MS/MS (negative ionization mode) spectral characterization of the Jamun fruit yoghurt

\begin{tabular}{|c|c|c|c|c|c|c|c|c|c|c|c|c|c|c|}
\hline $\begin{array}{l}\text { Source } \\
\text { of } \\
\text { variation }\end{array}$ & $\begin{array}{l}\text { Flavonol* } \\
\text { Molecular } \\
\text { ion; product } \\
\text { ions }(\mathrm{m} / \mathrm{z}) \\
\end{array}$ & $\frac{\text { M3glcU }}{493 ; 317}$ & $\begin{array}{l}\text { M3gal } \\
479 ; 317\end{array}$ & $\begin{array}{l}\text { M3glc } \\
479 ; 317\end{array}$ & $\begin{array}{l}\text { M3rhm } \\
463 ; 317\end{array}$ & $\begin{array}{l}\text { M3pent } \\
449 ; 317\end{array}$ & $\begin{array}{l}\text { L3gal } \\
493 ; 331\end{array}$ & $\begin{array}{l}\text { L3glc } \\
493 ; 331\end{array}$ & $\begin{array}{l}\text { S3gal } \\
507 ; 345\end{array}$ & $\begin{array}{l}\text { S3glc } \\
507 ; 345\end{array}$ & $\begin{array}{l}\text { Free } \\
\text { M } 317\end{array}$ & $\begin{array}{l}\text { Free } \\
\text { L } 331\end{array}$ & $\begin{array}{l}\text { Free } \\
\text { S } 345\end{array}$ & $\begin{array}{l}\text { Total } \\
\text { flavonols } \\
\mathrm{mg} / \mathrm{L}\end{array}$ \\
\hline \multicolumn{15}{|c|}{ Method of Jamun fruit juice extraction (M) } \\
\hline \multicolumn{2}{|c|}{$\begin{array}{l}\text { Cold blending } \\
\text { at } 1500 \mathrm{rpm}\end{array}$} & $0.198 \mathrm{a}$ & $0.192 \mathrm{a}$ & $2.368 \mathrm{a}$ & $0.350 \mathrm{a}$ & $0.310 \mathrm{a}$ & $0.093 \mathrm{a}$ & $0.232 \mathrm{~b}$ & $0.116 \mathrm{a}$ & $0.090 \mathrm{~b}$ & $0.979 \mathrm{~b}$ & $0.017 \mathrm{~b}$ & $0.038 \mathrm{a}$ & $2.18 \mathrm{a}$ \\
\hline \multicolumn{2}{|c|}{ Stem at $85 \pm 5^{\circ} \mathrm{C}$} & \multicolumn{13}{|c|}{ for $2 \mathrm{~h}$. } \\
\hline \multicolumn{2}{|c|}{$P$ value } & $<.0001$ & $<.0001$ & $<.0001$ & $<.0001$ & $<.0001$ & 0.0004 & $<.0001$ & $<.0001$ & $<.0001$ & $<.0001$ & $<.0001$ & $<.0001$ & $<.0001$ \\
\hline \multicolumn{15}{|c|}{ Percentage of Jamun fruit extract addition $(\mathrm{P})$} \\
\hline \multicolumn{2}{|c|}{$0 \%$ (control) } & $0.00 \mathrm{c}$ & $0.00 \mathrm{c}$ & $0.000 \mathrm{c}$ & $0.000 \mathrm{c}$ & $0.000 \mathrm{c}$ & $0.000 \mathrm{c}$ & $0.000 \mathrm{c}$ & $0.000 \mathrm{c}$ & $0.000 \mathrm{c}$ & $0.000 \mathrm{c}$ & $0.00 \mathrm{c}$ & $0.00 \mathrm{c}$ & $0.000 \mathrm{c}$ \\
\hline \multicolumn{2}{|l|}{$5 \%$} & $0.182 \mathrm{~b}$ & $0.142 b$ & $2.221 \mathrm{~b}$ & $0.337 \mathrm{~b}$ & $0.291 \mathrm{~b}$ & $0.102 \mathrm{~b}$ & $0.247 \mathrm{~b}$ & $0.098 \mathrm{~b}$ & $0.083 \mathrm{~b}$ & $1.169 \mathrm{~b}$ & $0.023 b$ & $0.026 \mathrm{~b}$ & $1.945 \mathrm{~b}$ \\
\hline \multicolumn{2}{|l|}{$10 \%$} & $0.306 a$ & $0.279 a$ & $4.622 \mathrm{a}$ & $0.653 \mathrm{a}$ & $0.524 \mathrm{a}$ & $0.171 \mathrm{a}$ & $0.483 \mathrm{a}$ & $0.213 \mathrm{a}$ & $0.194 \mathrm{a}$ & $2.370 \mathrm{a}$ & $0.074 \mathrm{a}$ & $0.079 a$ & $3.917 \mathrm{a}$ \\
\hline \multicolumn{2}{|l|}{$P$ value } & $<.0001$ & $<.0001$ & $<.0001$ & $<.0001$ & $<.0001$ & $<.0001$ & $<.0001$ & $<.0001$ & $<.0001$ & $<.0001$ & $<.0001$ & $<.0001$ & $<.0001$ \\
\hline \multicolumn{15}{|l|}{$\mathrm{MXP}$} \\
\hline \multicolumn{2}{|l|}{ Control } & 0.000 & 0.000 & 0.000 & 0.000 & 0.000 & 0.000 & 0.000 & 0.000 & 0.000 & 0.000 & 0.000 & 0.000 & 0.000 \\
\hline \multicolumn{2}{|c|}{ Cold blending x $5 \%$} & 0.230 & 0.206 & 2.382 & 0.364 & 0.331 & 0.113 & 0.252 & 0.098 & 0.072 & 0.961 & 0.000 & 0.020 & 2.163 \\
\hline \multicolumn{2}{|c|}{ Cold blending $\mathrm{x} 10 \%$} & 0.365 & 0.372 & 4.724 & 0.687 & 0.601 & 0.166 & 0.444 & 0.252 & 0.199 & 1.978 & 0.056 & 0.096 & 4.381 \\
\hline \multicolumn{2}{|c|}{ Steam extraction x $5 \%$} & 0.134 & 0.079 & 2.060 & 0.310 & 0.251 & 0.091 & 0.243 & 0.098 & 0.095 & 1.377 & 0.046 & 0.032 & 1.727 \\
\hline \multicolumn{2}{|c|}{ Steam extraction x $10 \%$} & 0.247 & 0.186 & 4.520 & 0.620 & 0.447 & 0.176 & 0.522 & 0.175 & 0.190 & 2.762 & 0.092 & 0.062 & 3.453 \\
\hline \multicolumn{2}{|l|}{$P$ value } & $<.0001$ & $<.0001$ & $<.0001$ & $<.0001$ & $<.0001$ & $<.0001$ & $<.0001$ & $<.0001$ & $<.0001$ & $<.0001$ & $<.0001$ & $<.0001$ & $<.0001$ \\
\hline
\end{tabular}

*M: myricetin; L: laricitrin; S: syringetin; glcU: glucuronide, gal: galactoside; glc: glucoside; rhm: rhamnoside; pent: pentoside.

Values with different letters (a-c) within the same column are significantly different at $\mathrm{P}<0.05$.

\subsection{Hydrolysable Tannins Spectral Characterization of the Jamun Fruit Yoghurt}

The results of Table (3) indicated that the application of steam at $85^{\circ} \mathrm{C}$ for $2 \mathrm{~h}$ in jamun juice extraction caused significant increments in the total gallotannins contents, which are referring to the total sum of gallic acid and its methyl ester in the jamun Yoghurt. That could be attributed to the covalent bonds' cleavage occurred through heating (Branco et al., 2016). Although the total ellagic acid contents took the same trends as the gallotannins, it was observed in relatively low concentrations. That could be due to that ellagitannins are very polar in case of the presence of many hydroxyl groups and hence very easy to be liberated (Nuengchamnong \& Ingkaninan, 2009). The extraction of juice with steam was associated with increasing the total ellagic acid in jamun Yoghurt in comparison with the cold extraction technique, possibly due to the enhanced release of ellagic acid from ellagitannins by hydrolysis during heating. These phenomena are in accordance with those reported by Fracassetti et al., 2013. The depending on cold blending for jamun fruit juice extraction led to decrease the levels of total vanoleic acid and total ellagitannins in the final fruit Yoghurt. Nevertheless, the levels of all determined hydrolysable tannins were increased by increasing the rate of jamun juice addition to the Yoghurt standardized milk. The total gallotannins were within $3.45-14.73 \mathrm{mg} / \mathrm{L}$; the highest value was for the steam extracted jamun Yoghurt with $10 \%$ juice. The lowest level of the hydrolysable tannins was for total vanoleic acid which is referring to the total sum of valoneic acid dilactone methyl ester and its isomer; it was ranging from 0.25 to 6.20 
$\mathrm{mg} / \mathrm{L}$.

Table 3. Ls means values for method of Jamun fruit juice extraction, percent of juice addition and method of Jamun fruit juice extraction $\mathrm{x}$ percent of juice addition on total hydrolysable tannins (as gallic acid for gallotannins; as ellagic acid for ellagitannins) of the Jamun fruit yoghurt

\begin{tabular}{|c|c|c|c|c|}
\hline Source of variation & $\begin{array}{l}\text { Total gallotannins } \\
(m g /)\end{array}$ & $\begin{array}{l}\text { Total ellagic acid } \\
(m g / L)\end{array}$ & $\begin{array}{l}\text { Total vanoleic acid } \\
(m g /)\end{array}$ & $\begin{array}{l}\text { Total ellagitannins } \\
(m g /)\end{array}$ \\
\hline \multicolumn{5}{|c|}{ Method of Jamun fruit juice extraction (M) } \\
\hline Cold blending at $1500 \mathrm{rpm}$ & $3.521^{\mathrm{b}}$ & $0.398^{\mathrm{b}}$ & $0.275^{\mathrm{b}}$ & $0.659^{\mathrm{b}}$ \\
\hline Stem at $85 \pm 5^{\circ} \mathrm{C}$ for $2 \mathrm{~h}$. & $7.474^{\mathrm{a}}$ & $2.959^{\mathrm{a}}$ & $3.186^{\mathrm{a}}$ & $5.947^{\mathrm{a}}$ \\
\hline$P$ value & $<.0001$ & $<.0001$ & $<.0001$ & $<.0001$ \\
\hline \multicolumn{5}{|c|}{ Percentage of Jamun fruit extract addition $(\mathrm{P})$} \\
\hline $0 \%$ (control) & $0.000^{c}$ & $0.000^{\mathrm{c}}$ & $0.000^{\mathrm{c}}$ & $0.000^{\mathrm{c}}$ \\
\hline $5 \%$ & $5.571^{\mathrm{b}}$ & $1.637^{\mathrm{b}}$ & $1.803^{\mathrm{b}}$ & $3.143^{\mathrm{b}}$ \\
\hline $10 \%$ & $10.922^{\mathrm{a}}$ & $3.399^{\mathrm{a}}$ & $3.390^{\mathrm{a}}$ & $6.767^{\mathrm{a}}$ \\
\hline Pvalue & $<.0001$ & $<.0001$ & $<.0001$ & $<.0001$ \\
\hline \multicolumn{5}{|l|}{ M X P } \\
\hline Control & 0.000 & 0.000 & 0.000 & 0.000 \\
\hline Cold blending x $5 \%$ & 3.452 & 0.412 & 0.254 & 0.665 \\
\hline Cold blending x $10 \%$ & 7.111 & 0.783 & 0.573 & 1.313 \\
\hline Steam extraction x $5 \%$ & 7.690 & 2.863 & 3.352 & 5.620 \\
\hline Steam extraction $\mathrm{x} 10 \%$ & 14.733 & 6.015 & 6.207 & 12.222 \\
\hline$P$ value & $<.0001$ & $<.0001$ & $<.0001$ & $<.0001$ \\
\hline
\end{tabular}

Values with different letters (a-c) within the same column are significantly different at $\mathrm{P}<0.05$.

\subsection{Antioxidant Activity of the Jamun Fruit Yoghurt}

As shown in Table (4) the antioxidant activity indicators of the jamun-containing Yoghurt experimental samples were significantly higher than those of the control plain sample which was made without jamun juice. Concerning the DPPH radical scavenging activity, data revealed that the depending on steam for jamun fruit juice extraction for the application in fruit Yoghurt caused to increase the DPPH \% of Yoghurt when compared to the cold extraction method. That could be ascribed essentially to the considerably high hydrolysable tannins contents of the steam extracted jamun Yoghurt samples, with its $-\mathrm{oH}$ groups of the aromatic rings which enable the tannins to form complexes with other macromolecules. These observations were supported by the previous findings of Amoako \& Awika, 2016. Furthermore, the DPPH radical scavenging activity was increased in the jamun containing yoghurt in a dose-depending style, as the control sample obtained the lowest significant value, followed by the yoghurt with 5\% juice then the samples with $10 \%$ juice. The inhibition degree of ABTS radical formation was increased in the fruit yoghurt samples when compared to the control plain one. The ABTS radical scavenging activities of yogurt reached its highest value in the $10 \%$ steam extracted juice containing sample, while the lowest value was for the control Yoghurt. Moreover, the control Yoghurt reflected a relatively high reducing power activity possibly due to the lactic acid bacteria metabolic activity; this high reducing power was increased significantly when the jamun juice was incorporated into Yoghurt milk. It is worth noting to mention that the increase in the reducing power of Yoghurt with the addition of jamun extracts could be ascribed essentially to the phytochemical content of the jamun pulp (Sarkar et al., 2015). Likewise, the highest reducing power activity was achieved when the steam extraction method was applied. This phenomenon was in accordance with the results of Gong et al., 2012 who studied the effect of treatment with steam on the antioxidant capacity of barley bran.

\subsection{Sensory Evaluation of Jamun Fruit Yoghurt}

As declared from Figures (1, 2 and 3), the application of the cold blending method for jamun fruit juice extraction was associated with the highest significant values of thickness and smell, while the other extraction method i.e., the steam one was distinguished with the increased values of color, appearance, flavor, taste and overall acceptability. The increase in the Yoghurt taste and flavor scoring upon application of steam extraction could be ascribed to the effect of heating on the breakdown of carbohydrates into different soluble sugar compounds, leading to support the yoghurt taste and aroma (Pantastico, 1986). Regarding the effect of the percentage of jamun fruit extract addition, the control plain Yoghurt got the highest scores of appearance and thickness, as well as the lowest score of smell. Adding the fruit extract at a dose of $5 \%$ led to enhance the 
Yoghurt color, flavor, taste smell and total acceptability, as well as to reduce the scores of appearance and thickness. On the other hand, the Yoghurt of $10 \%$ fruit extract kept its smell score higher than the control and took the lowest scores of all other judging criteria. It is noteworthy to mention that all the experimental Yoghurt samples were totally accepted by the panellists as their overall acceptability scores were more than 5 out of 9 and the highest overall organoleptic acceptability was for the Yoghurt of 5\% steam extracted jamun juice.

Table 4. Ls means values for method of Jamun fruit juice extraction, percent of juice addition and method of Jamun fruit juice extraction $\mathrm{x}$ percent of juice addition on the antioxidation power indicators of the Jamun fruit yoghurt

\begin{tabular}{llll}
\hline Source of variation & $* D P P H(\%)$ & $A B T S(\%)$ & Reducing power (\%) \\
\hline \multicolumn{2}{l}{ Method of Jamun fruit juice extraction (M) } & & \\
Cold blending at 1500 rpm & $72.23^{\mathrm{b}}$ & $62.44^{\mathrm{b}}$ & $32.16^{\mathrm{b}}$ \\
Stem at $85 \pm 5^{\circ} \mathrm{C}$ for 2 h. & $75.63^{\mathrm{a}}$ & $65.84^{\mathrm{a}}$ & $34.44^{\mathrm{a}}$ \\
$P$ value & $<.0001$ & $<.0001$ & $<.0001$ \\
Percentage of Jamun fruit extract addition $(\mathrm{P})$ & \\
$0 \%($ control) & $62.55^{\mathrm{c}}$ & $48.74^{\mathrm{c}}$ & $30.64^{\mathrm{c}}$ \\
$5 \%$ & $74.83^{\mathrm{b}}$ & $66.75^{\mathrm{b}}$ & $33.79^{\mathrm{b}}$ \\
$10 \%$ & $84.41^{\mathrm{a}}$ & $76.93^{\mathrm{a}}$ & $35.48^{\mathrm{a}}$ \\
$P$ value & $<.0001$ & $<.0001$ & $<.0001$ \\
$\mathrm{M}$ X P & & & \\
Control & 62.55 & 48.74 & 30.64 \\
Cold blending x 5\% & 72.28 & 64.20 & 32.74 \\
Cold blending x 10\% & 81.86 & 74.38 & 33.12 \\
Steam extraction x 5\% & 77.38 & 69.30 & 34.84 \\
Steam extraction x 10\% & 86.96 & 79.48 & 37.84 \\
$P$ value & $<.0001$ & $<.0001$ & $<.0001$ \\
\hline
\end{tabular}

* DPPH: 2,2-diphenyl-1-picrylhydrazyl; ABTS: 2,2'-azino-bis-3-ethylbenzothiazoline- 6-sulfonic acid.

Values with different letters $(\mathrm{a}-\mathrm{c})$ within the same column are significantly different at $\mathrm{P}<0.05$.

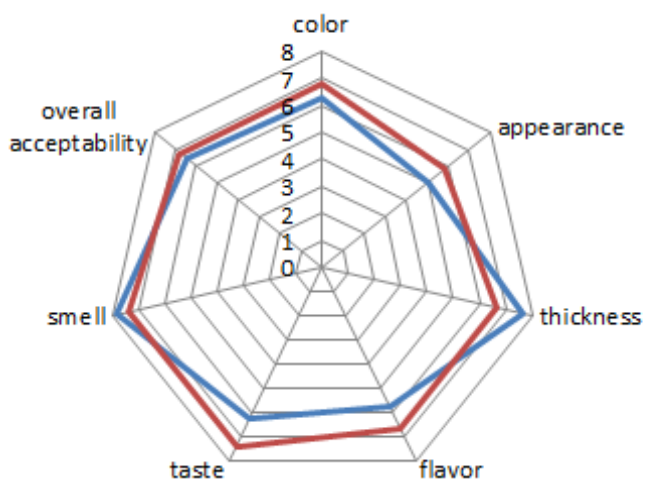

Cold blending at $1500 \mathrm{rpm}$

Stem at at $85 \pm 5^{\circ} \mathrm{C}$ for $2 \mathrm{~h}$

Figure 1. Effect of jamun fruit juice extraction method on the sensorial scoring of the jamun fruit Yoghurt

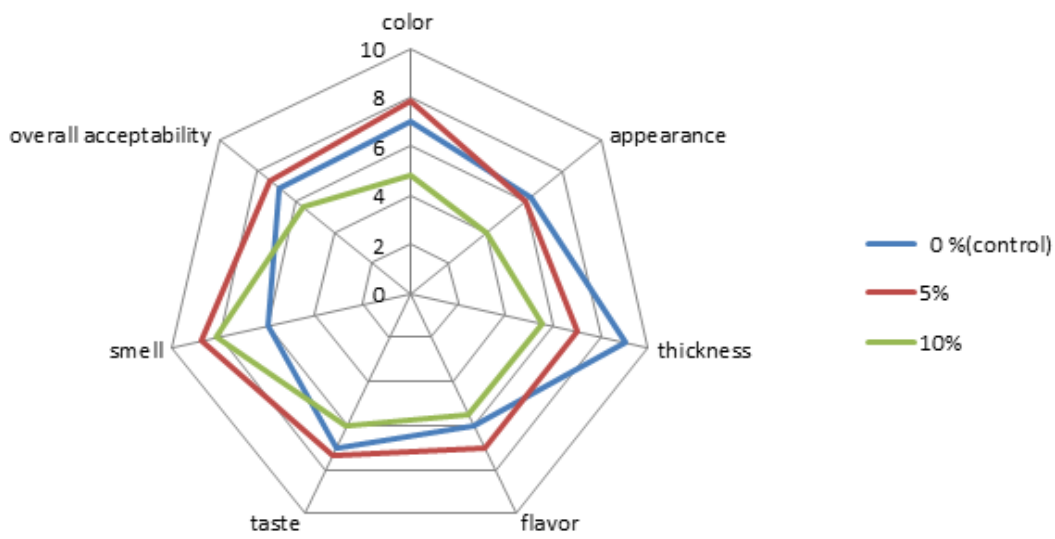

Figure 2. Effect of percent of jamun fruit juice addition to the Yoghurt standardized milk on the sensorial scoring of the jamun fruit Yoghurt 


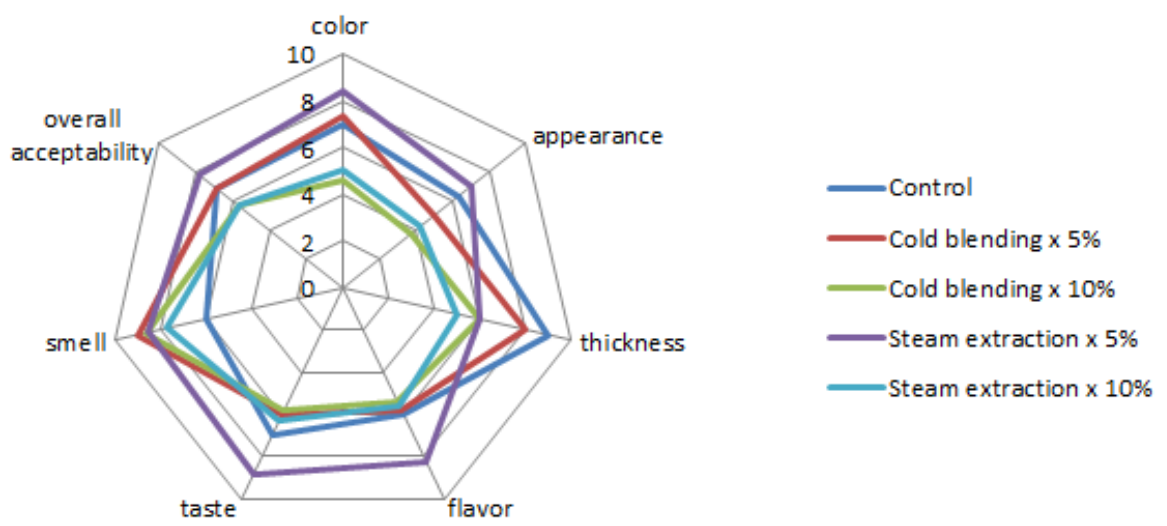

Figure 3. Effect of the interaction between the method of jamun juice extraction and percent of jamun fruit juice addition to the Yoghurt standardized milk and on the sensorial scoring of the jamun fruit Yoghurt

\section{Conclusion}

In this study, Jamun fruit was subjected to either mechanical cold extraction or steam extraction and added to the Yoghurt milk at rates of 5 and $10 \%$, to evaluate its effects on the flavonols profiles, antioxidant activity and sensorial characteristics of the final Yoghurt product. The study findings led to conclude that, Jamun fruit may be a promising source for fortifying Yoghurt with flavonols and enhancing its antioxidant power and its overall sensorial acceptability.

\section{References}

Abdel-Hamid, M., Romeih, E., Huang, Z., Enomoto, T., Hung, L., \& Li, L. (2020). Bioactive properties of probiotic set-yogurt supplemented with Siraitia grosvenorii fruit extract. Food Chemistry, 303, 125400. https://doi.org/10.1016/j.foodchem.2019.125400

Amoako, D., \& Awika, J. M. (2016). Polyphenol interaction with food carbohydrates and consequences on availability of dietary glucose. Curr. Opin. Food Sci., 8, 14-18. https://doi.org/10.1016/j.cofs.2016.01.010

Association of Official Analytical Chemists. AOAC. (2007). Official Method of Analysis (18th ed.). Benjamin Franklin Station Washington DC, USA. pp. 302-850.

Astuti, S. D., Salengke, S. B., Laga, A., Bilangd, M., Mochtar, H., \& Warisf, A. (2018). Characteristics of pH, Total Acid, Total Soluble Solid on Tomato Juice by Ohmic Heating Technology. International Journal of Sciences: Basic and Applied Research, 39, 21-28.

Branco, I. G., Moraes, I. C. F., Argandoña, E. J. S., Madrona, G. S., dos Santos, C., Ruiz, A. L. T. G., \& Haminiuk, C. W. I. (2016). Influence of pasteurization on antioxidant and in vitro anti-proliferative effects of jambolan (Syzygium cumini (L.) Skeels) fruit pulp. Industrial Crops and Products, 89, 225-230. https://doi.org/10.1016/j.indcrop.2016.04.055

Castillo-Muñoz, N., Gómez-Alonso, S., García-Romero, E., Gómez, M. V., Velders, A. H., \& Hermosín-Gutiérrez, I. (2009). Flavonol 3-O-glycosides series of Cv. Petit Verdot red wine grapes. Journal of Agricultural and Food Chemistry, 57, 209-219. https://doi.org/10.1021/jf802863g

Chaudhary, B., \& Mukhopadhyay, K. (2012). Syzygium cumini (L.) skeels: a potential source of nutraceuticals. Int J Pharm Biol Sci, 2, 46e53.

Chen, G., \& Chen, H. (2011). Extraction and deglycosylation of flavonoids from sumac fruits using steam explosion. Food Chemistry, 126, 19334-1938. https://doi.org/10.1016/j.foodchem.2010.12.025

Cheung, L. M., Cheung, P. C. K., Ooi, V. E. C. (2003). Antioxidant activity and total phenolics of edible mushroom extracts. Food Chem., 81, 249-255. https://doi.org/10.1016/S0308-8146(02)00419-3

Coïsson, J. D., Travaglia, F., Piana, G., Capasso, M., \& Arlorio, M. (2005). Euterpe oleracea juice as a functional pigment for yogurt. Food Res Int, 38, 893-897. https://doi.org/10.1016/j.foodres.2005.03.009

Fracassetti, D., Costa, C., Moulay, L., \& Tomás-Barberán, F. A. (2013). Ellagic acid derivatives, ellagitannins, proanthocyanidins and other phenolics, vitamin $\mathrm{C}$ and antioxidant capacity of two powder products from camu-camu fruit (Myrciaria dubia). Food Chemistry, 139, 578-588. 
https://doi.org/10.1016/j.foodchem.2013.01.121

Ghosh, P., Pradhan, R. C., Mishra, S., Patel, A. S., \& Kar, A. (2016). Physicochemical and Nutritional Characterization of Jamun (Syzygium Cuminii). Curr Res Nutr Food Sci., 4(2).

https://doi.org/10.12944/CRNFSJ.5.1.04

Gong, L., Huang, L., \& Zhang, Y. (2012). Effect of steam explosion treatment on barley bran phenolic compounds and antioxidant capacity. J. Agric. Food Chem., 60, 7177-7184. https://doi.org/10.1021/jf301599a

Joshi, M., Paudel, M., \& Upreti, S. (2019). Therapeutic influence of Jamun (Syzygium cumini): A review. Journal of Pharmacognosy and Phytochemistry, 8, 1056-1059.

Kapoor, S., Ranote, P. S., \& Sharma, S. (2015). Bioactive components and quality assessment of jamun (Syzygium cumini L.) powder supplemented chapatti. Indian Journal of Science and Technology, 8, 287-295. https://dx.doi.org/10.17485/ijst/2015/v8i3/59863

Kim, K. H., Hwang, H. R., Jo, J. E., Lee, S. Y., Kim, N. Y., \& Yook, H. S. (2009). Quality characteristics of yogurt prepared with flowering cherry (Prunus serrulata L. var. spontanea Max. wils.) fruit powder during storage. J Korean Soc Food Sci Nutr., 38, 1229-1236. https://doi.org/10.3746/jkfn.2009.38.9.1229

Kulshrestha, N., Jha, Y. K., \& Chopra, C. S. (2006). Studies on preparation of fruit yoghurt. Beverage \& Food World. pp. 67-69.

Morelli, L. (2014). Yogurt, living cultures, and gut health. Am J Clin Nutr, 99, 1248S-50. https://doi.org/10.3945/ajcn.113.073072

Muniandy, P., Shori, A. B., \& Baba, A. S. (2016). Influence of green, white and black tea addition on the antioxidant activity of probiotic yogurt during refrigerated storage. Food Packag Shelf Life, 8, 1-8. https://doi.org/10.1016/j.fpsl.2016.02.002

Nguyen, L., \& Hwang, E. (2016). Quality Characteristics and Antioxidant Activity of Yogurt Supplemented with Aronia (Aronia melanocarpa) Juice. Prev. Nutr. Food Sci., 21, 330-337. https://doi.org/10.3746/pnf.2016.21.4.330

Nuengchamnong, N., \& Ingkaninan, K. (2009). On-line characterization of phenolic antioxidants in fruit wines from family myrtaceae by liquid chromatography combined with electrospray ionization tandem mass spectrometry and radical scavenging detection. LWT-Food Science and Technology, 42, 297-302.

https://doi.org/10.1016/j.lwt.2008.04.012

Obi, T. E., Henshaw, F. O., \& Atanda, O. O. (2010). Quality evaluation of plain-stirred probiotic yoghurt produced from skim and whole milk powder during refrigerated strorage. EJEAFChe, 9, 1203-1213.

Oh, H. S., \& Kang, S. T. (2015). Quality characteristics and antioxidant activity of yogurt added with acanthopanax powder. Korean J Food Sci Technol., 47, 765-771. https://doi.org/10.9721/KJFST.2015.47.6.765

Oyaizu, M. (1986). Studies on products of browning reaction antioxidative activities of products of browning reaction prepared from glucosamine. Jpn J Nutr Diet, 44, 307-315. https://doi.org/10.5264/eiyogakuzashi.44.307

Pantastico, E. B. (1986). Fisiologi Pasca Panen. Universitas Gadjah Mada, Yogyakarta.

Peng, S., Scalbert, A., \& Monties, B. (1991). Insoluble ellagitannins in Castanea sativa and Quercus petraea woods. Phytochemistry, 30, 775-778. https://doi.org/10.1016/0031-9422(91)85250-4

Rahman, M. T., Abu Zubair, M. D., Shima, K., \& Chakma, M. P. (2020). Development of quality parameters for yogurt with strawberry juice. Food and Nutrition Sciences, 11, 1070-1077. https://doi.org/10.4236/fns.2020.1112075

Re, R., Pellegrini, N., Proteggente, A., Pannala, A., Yang, M., \& Rice-Evans, C. (1999). Antioxidant activity applying an improved ABTS radical cation decolorization assay. Free Radic Biol Med., 26, 1231-1237. https://doi.org/10.1016/S0891-5849(98)00315-3

Sarkar, P., Kumar, L., Dhumal, C., Panigrahi, S., \& Choudhary, R. (2015). Traditional and ayurvedic foods of Indian origin. J Ethn Foods, 2, 97-109. https://doi.org/10.1016/j.jef.2015.08.003

SAS. Statistical Analysis System. (2004). SAS/STAT ${ }^{\circledR} 9.1$ User's Guide. SAS Inst Inc Ed Cary NC USA.

Singh, J. P., Kaur, A., Singh, N., Nim, L., Shevkani, K., Kaur, H., \& Arora, D. S. (2016). In vitro antioxidant and 
antimicrobial properties of jambolan (Syzygium cumini) fruit polyphenols. LWT-Food Science and Technology, 65, 1025-1030. https://doi.org/10.1016/j.lwt.2015.09.038

Tavares, I. M. C., Lago-Vanzela, E. S., Rebello, L. P. G., Ramos, A. M., Gómez-Alonso, S., García-Romero, E., \& Hermosín-Gutiérrez, I. (2016). Comprehensive study of the phenolic composition of the edible parts of jambolan fruit (Syzygium cumini (L.) Skeels). Food Research International, 82, 771-779. https://doi.org/10.1016/j.foodres.2016.01.014

Teleszko, M., Nowicka, P., \& Wojdyło, A. (2016). Effect of cultivar and storage temperature on identification and stability of polyphenols in strawberry cloudy juices. Journal of Food Composition and Analysis, 54, 10-19. https://doi.org/10.1016/j.jfca.2016.09.009

Wallace, T. C., \& Giusti, M. M. (2008). Determination of color, pigment, and phenolic stability in yogurt systems colored with nonacylated anthocyanins from Berberis boliviana L. as compared to other natural/synthetic colorants. J Food Sci., 73, C241-C248. https://doi.org/10.1111/j.1750-3841.2008.00706.x

\section{Copyrights}

Copyright for this article is retained by the author(s), with first publication rights granted to the journal.

This is an open-access article distributed under the terms and conditions of the Creative Commons Attribution license (http://creativecommons.org/licenses/by/4.0/). 